\title{
Effect of Application of Vermicompost and Conventional Compost Derived from Different Residues on Pea Crop Production and Soil Faunal Diversity in Agricultural System in Garhwal Himalayas India
}

\author{
Tunira Bhadauria ${ }^{1}$, Pradeep Kumar $^{1}$, Rakesh Maikhuri², Krishan Gopal Saxena ${ }^{3}$ \\ ${ }^{1}$ Department of Zoology, Feroze Gandhi Post Graduate College, Raebareli, India \\ ${ }^{2}$ G.B. Pant Institute of Himalayan Environment and Development, Garhwal Unit, Srinagar, India \\ ${ }^{3}$ School of Environmental Sciences, Jawaharlal Nehru University, New Delhi, India \\ Email: tunira@gmail.com
}

Received 10 February 2014; revised 10 March 2014; accepted 17 March 2014

Copyright (C) 2014 by authors and Scientific Research Publishing Inc.

This work is licensed under the Creative Commons Attribution International License (CC BY). http://creativecommons.org/licenses/by/4.0/

(c) (i) Open Access

\section{Abstract}

Sedentary crop-livestock mixed farming is the predominant agricultural land use in Central Himalaya upland and largely rainfed; agrochemicals are not used at all. Farmers focus on increasing yields with poor soil fertility management practices resulted in sharp decline in production of pea crop in the study site. Therefore in present study options are being looked into devising some conservation strategies that increase yields of pea while reducing harm to soil biodiversity at a local scale here. The present study explores the efficiency of $P$. excavatus as endemic earthworm species for vermicomposting, the potential utilization of Conventional oak based farmyard manure (FM-0); Conventional pine based farmyard manure(FM-P); Earthworm fed - Cow dung + oak leaves based vermicompost (VC-0); Earthworm fed - Cow dung + pine leaves based vermicompost (VC-P); freshly fallen leaf litter (LM) on pea crop productivity and soil faunal diversity in agricultural system, and if the changed soil faunal biodiversity scenario in any way affected the crop production. The higher uptake of nitrogen, higher germination percentage enhanced seedling growth, early emergence flower, increase number of pods, seed, husk, and root biomass was significantly higher in plants which received VC-O followed by VC-P as manure input treatments. The change in the diversity of soil micro arthropods in relation to quality change in organic residues input in experimental plots and expressed as the Simpsons diversity index showed that the diversity of soil

\footnotetext{
*Corresponding author.
} 
fauna is related to improvements in soil conditions resulting from nutrient manipulations through vermicompost and conventional compost treatments. This response of soil biota to increased production most likely represents an increase in the availability of resources through addition of vermicompost when compared to other compost treatments. Alternatively, an increase in predators and therefore predation, could, increase the diversity of its prey, thereby decreasing dominant competitors and reducing the possibility of competitive exclusion, but this needs further studies. Chronosequence study during cropping season indicated that the composition and abundance of soil fauna in agricultural fields changed considerably with time under cultivation. This technology has now been adopted by the farmers in the area once again for growing the pea crop.

\section{Keywords}

Himalayas, Crop-Livestock Mixed Farming, Vermicompost, Conventional Composts, Pea Crop Production, Cropping Pattern, Soil Faunal Diversity

\section{Introduction}

Traditional farmers are dependent on forest biomass for fodder, manure and a range of woody and non-woody products used to sustain traditional farming and livelihoods, they also depend heavily on farmyard manure to replenish soil fertility in croplands [1]. They are not aware of the fact that it is not only the quantity but also the chemical and biological quality of manure, which determines yields, and food quality of the crops. Earthworms are important biological organisms that maintain nutrients flow specially playing an important role in the recycling of $\mathrm{N}$ in different agro ecosystems [2] [3]. Farmers are aware of earthworms as a beneficial organism but are not of the technology of vermicompost production and its advantages over traditional farmyard manure. Vermicompost serves as an important component of integrated plant nutrient supply system for balanced fertilization along with maintaining health to sustain the productivity of soils [4]. Agroecosystems deprived of their biological diversity result in costly external inputs, because of the inability to sponsor their own soil fertility and pest regulation. Enhancing functional biodiversity in agricultural systems is a key ecological strategy to bring sustainability to the production [5]. The mix of soil organisms in the soil also partially determines soil resilience. Residue recycling is a key factor in determining the soil biotic activity and species faunal diversity management in agro ecosystems. Farmers in this region are dependent on forest biomass for fodder and manure and are more reliant on biological functioning of the soil, due to the reliance of cropping systems on organic inputs for management of soil fertility. Sedentary crop-livestock mixed farming is the predominant agricultural land use, in relatively cooler-less humid Central and Western Himalaya upland agro ecosystems and largely rain fed. Traditionally around $20 \mathrm{t}^{\mathrm{h}} \mathrm{ha}^{-1}$ of farm yard manure is applied annually in each hectare of cropland and $20-30 \mathrm{~cm}$ deep ploughing done. But since last few years farmers focus on increasing yields with continuous cropping on the same plot of land with reduced input of organic matter into soil, has altered the soil habitats and structure of communities of soil fauna causing a sharp decline in soil fertility and depletion in production of many important crops, especially pea crop. The present study therefore aims to explore the potential utilization of application of vermicompost and conventional compost derived from different residues on improving pea crop production as well as soil faunal diversity. This will be done with the aim to devise a strategy for improving the crop production in the region where it has depleted due to poor land management practices. Endemic earthworm P. excavatus has been used as species for vermicomposting.

\section{Methods}

\subsection{Description of Study Site}

The study was carried out at Bhiri-Banswara village landscape (latitude $30^{\circ} 27^{\prime} \mathrm{N}$ and $79^{\circ} 5^{\prime} \mathrm{E}$ ) in Chamoli district in Central Himalayan region of India at an elevation of 1100 - $1200 \mathrm{~m}$ above mean sea level. The landscape is a mosaic of agroecosystems, forests and degraded ecosystems. The soil is classified as Dystric Cambisol according to FAO system. 


\subsection{Preparation of Vermicompost}

The culture medium used for growing earthworms (vermibeds) were prepared following standard method of Kale and Bano [6]. Two types of the vermibeds were prepared: (i) Oak mixed broad leaf litter + cow dung in 1:2 ratio (iii) Pine litter + cow dung in 1:2 ratio. Following pre composting mature Perionyx excavatus released into the tanks (4500 worms/tank) and in three months, vermicompost was sieved, separated and stored in bags for putting into the experimental plots. Farmers follow the traditional practice of composting agriculture and animal waste in the compost pits before applying to the land. Composted oak-based farmyard manure (cow dung + leaves of oak) as well as composted pine based farmyard manure (cow dung + leaves of pine) were collected locally from the villagers and leaf litter was collected from the forest surrounding the village.

\subsection{Experimental Set up}

Three replicate plots $\left(462 \mathrm{~m}^{2}\right.$ ), with 50 - $100 \mathrm{~m}$ distance between adjacent plots were demarcated. All plots were selected on south-facing slopes over an elevation range of 1100 - $1150 \mathrm{~m}$ to maximize the effect of land use. Experimental plot comprised of 30 units of $2 \mathrm{~m}^{2}$ each, randomly allocated to six treatments, all the experimental units were distributed on a randomized block design, each block contained 5 replicates per treatment for pea crop growth and yield study, and for soil faunal sampling.

1) Control - Without any amendments (C)

2) Conventional oak based farmyard manure (cow dung + leaves of oak) collected from the surrounding forests (FM-O)

3) Conventional pine based farmyard manure (cow dung + leaves of pine) (FM-P)

4) Earthworm fed - cow dung + oak leaves based vermicompost (VC-O)

5) Earthworm fed - cow dung + pine leaves based vermicompost (VC-P)

6) leaf litter (LM)

The amount of organic matter applied in form of (FM-O), (FM-P), (VC-O), (VC-P), and (LM) for experiment was calculated by its nutrient equivalent so that the same amount of nitrogen $(120 \mathrm{~kg} / \mathrm{ha})$ was applied under different treatments. Thus (FM-O) and (FM-P)@12t/ha and 13.1t/ha, (VC-O) and (VC-P)@6t/ha and 8t/ha and (LM)@15.t/ha were applied a week before the sowing of the pea seeds (15 November 2011) in each treatment, twenty plants were planted in a unit of the micro plot and weeds removed manually after three and six weeks of seed germination. Majority of agriculture in Himalayas is rain fed therefore, no irrigation was required during cropping here. Since there was a monkey menace in the locality, experimental plot was enclosed from all the four sides by a net enclosure of about 10 feet high as protection against monkeys, besides regular monitoring (chaukidari) by one person. The fruits were harvested on 12 March 2012 when pods were mature and green. At the time of harvesting ten plants were selected randomly from each treatment, the plants so collected were washed in tap water and subsequently kept in hot air oven at $60^{\circ} \mathrm{C}$ for 24 hours and then, weight of fruit, husk, stem, and roots were recorded.

\subsection{Soil Sampling}

Composite soil samples (to a depth of 0 - $30 \mathrm{~cm}$ ) were randomly drawn from each replicate plot of experimental area before sowing of the seeds and after crop harvesting was done and was analyzed for physical and chemical properties. Each monolith subdivided into 0 - 10, 10 - $20 \mathrm{~cm}$ blocks, the soil samples were air dried and sieved through a 2-mm sieve. A representative of the sub-sample was stored for subsequent analysis. Soil temperatures recorded weekly at $0-10$ and $10-20 \mathrm{~cm}$ depths; however, the values presented here are mean monthly values for $0-10 \mathrm{~cm}$ depth (Figure 1(a)). Soil moisture was recorded every month at $0-10$ and $10-20 \mathrm{~cm}$ depths, but the values presented here are mean monthly values for $0-10 \mathrm{~cm}$ depth and are expressed as \% oven dry weight at $105^{\circ} \mathrm{C}$ (Figure $1(\mathbf{b})$ ).

Analysis of soil texture was done using a hydrometer method [7], soil pH was measured as 1:2.5 (soil: water) solution. Bulk density was estimated using standard method [8], total nitrogen in the experimental field soil and vermicompost was determined by the Kjeldahl method and organic carbon was estimated by Walkey Black method [9]. Carbon content of litter and farmyard manure was determined based on loss of ignition at $550^{\circ} \mathrm{C}$ for 8 hours and Nitrogen was estimated by the micro-Kjeldahl method [10]. Soil was sampled before the sowing of crops and then after the crop harvested under all the treatments. A separate table added showing the mean values of the experimental soil profile before cropping was initiated (Table 1). 


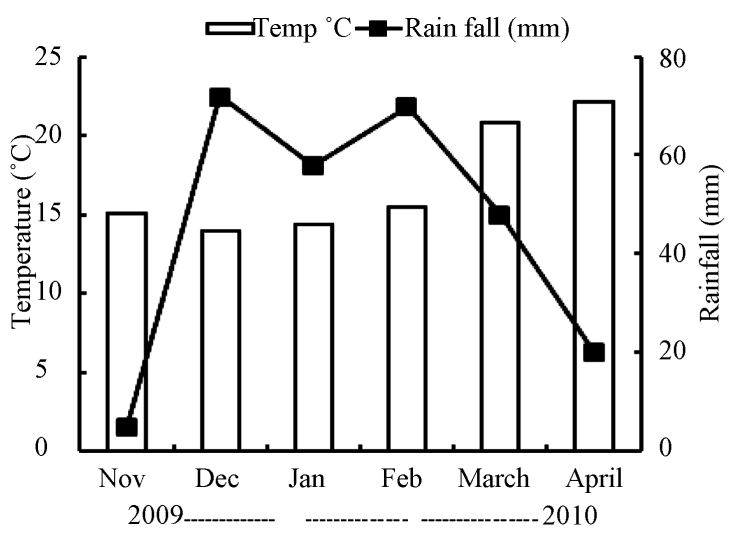

(a)

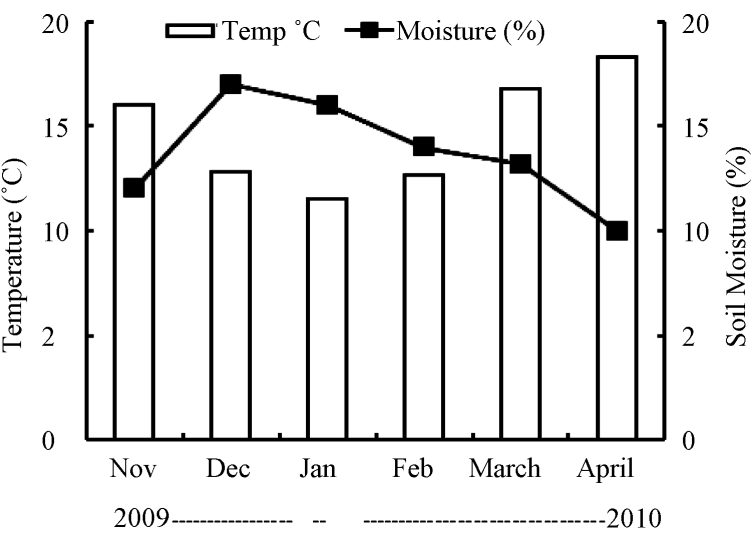

(b)

Figure 1. Average monthly fluctuation in atmospheric temperature and rainfall (Figure 1(a)), and in soil temperature and moisture (Figure 1(b)) during the cropping season in agricultural system in Bhiri-Banswara village.

Table 1. Physico-chemical characteristics of soil $( \pm \mathrm{SE}, \mathrm{n}=5)$ in experimental plots before start of experiments in Bhiri-Banswara village.

\begin{tabular}{cc}
\hline Soil Characteristics & \\
\hline Sand (\%) & $54.8 \pm 3.2$ \\
Silt (\%) & $27.2 \pm 1.6$ \\
Clay (\%) & $18.0 \pm 1$ \\
pH & $6.3 \pm 0.3$ \\
BD (g. $\left.\mathrm{cm}^{-3}\right)$ & $1.3 \pm 0.3$ \\
OC (\%) & $1.6 \pm 0.2$ \\
N (\%) & $0.11 \pm 0.02$ \\
C:N & $14.4 \pm 1.0$ \\
\hline
\end{tabular}

\subsection{Soil Fauna Sampling}

8 to 10 individual pitfall traps (6cm diameter and $5 \mathrm{~cm}$ in length) were established to trap surface active macro fauna and Collembola (Entomobryomorpha and Sminthurids) and then preserved in 70\% - 90\% isopropyl (rubbing alcohol). Berlese funnels were used to extract Acarina and Collembola (Podumorphs) from litter and soil samples using soil corers $\left(5 \times 5 \times 7 \mathrm{~cm}^{3}\right.$ size), and then preserved in absolute alcohol with few drops of glycerin added to them.

\subsection{Arthropod Biomass Estimation}

Biomass of preserved macro arthropods that is coleoptera, hymenoptera, larvae and arachnids were determined by weighing them on single pan electronic balance $(0.0001 \mathrm{gm})$ after wiping them dry on filter paper. For meso arthropods that are Entomobryomorphid, Sminthurids, Podumorphs and Acarina, hundred preserved specimens of each group were taken. These were placed on a filter paper in a petri-dish, their weight taken (A), on single pan electronic balance (0.0001 gm). Subsequently the specimen were removed and the weight of only Petri-dish and filter paper taken (B), the weight of Entomobryomorphid, Sminthurids, Podumorphs and Acarina then determined by substracting (A-B).

\subsection{Statistical Analysis of the Data}

Statistical analysis is done using standard biostatistical methods [11]. Significant differences in physico-chemical characteristics of the soil across different treatments carried out using one-way ANOVA. Significant differences 
in the density and biomass of soil macro and meso arthropod samples across different sampling treatments and in between the same treatment was tested using non-parametric one-way ANOVA (F-test), and the New Mann Keul's multiple range tests (q-test). Sample standard error was calculated as the standard error of the Mean ( \pm SE).

\subsection{Diversity Index Calculated as Simpsons Index of Diversity}

$$
D=\Sigma[n(n-1) / N(N-1)]
$$

where $n=$ total number of organisms of particular species; $N=$ total number of organisms of all the species; and the value of $\mathrm{D}$ ranges between 0 and 1.

\section{Results}

\subsection{Soil Physico-Chemical Characteristic}

The mean values of the soil profile subsequent to harvest of crops in experimental plots is described in Table 2, thus, soil pH was higher in VC-O compared to control and other treatments. Soil Bulk densities were lower in VC-O and VC-P. Organic carbon percentage varied significantly between different treatments $(F \cdot[5,12]=$ 232.12; $\mathrm{P}<0.05)$ and was significantly higher in both VC-O (q [12,6] = 39.43; $\mathrm{P}<0.05)$ and VC-P $(\mathrm{q}[12,6]=$ 33.23; $\mathrm{P}<0.05)$ compared to all other treatments, but these values did not vary significantly with in VC-P and VC-O and also between FM-O and FM-P treatments. Total Nitrogen also varied significantly between different treatments (F.[5,12] = 13.86; $\mathrm{P}<0.05)$ and was significantly higher in VC-O (q $[12,6]=10.77 ; \mathrm{P}<0.05)$ and in VC-P (q $[12,6]=4.39$; $\mathrm{P}<0.05)$ as compared to FM-O, FM-P and C treatments. Also soil C: $\mathrm{N}$ ratio was lower in VC-O and VC-P treated plots as compared to C, FM-O, and FM-P treated plots (Table 2).

\subsection{Chemical Composition of LM, FM-0, FM-P VC-O and VC-P}

Organic carbon percentage was significantly higher in fresh litter $(\mathrm{F}[5,12]=125$; $\mathrm{P}<0.05)$ when compared to the FM-O, FM-P and VC-P, VC-O. Total nitrogen percentage was significantly higher in the VC-O $(\mathrm{q}[12,6]=$ 27; $\mathrm{P}<0.05)$ and VC-P (q [12,6] = 32.34; $\mathrm{P}<0.05)$. C: $\mathrm{N}$ ratio was much lower VC-O (q [12, 6] = 19.53; $\mathrm{P}<$ $0.05)$ and VC- $\mathrm{P}(\mathrm{q}[12,6]=24.43 ; \mathrm{P}<0.05)$ when compared to FM-O and FM-P (Table 3).

Table 2. Physico-chemical characteristics of soil under different treatments subsequent to the crop harvest $( \pm \mathrm{SE}, \mathrm{n}=5$; Average mean values subsequent to the crop harvest). Values for any variable with different superscript letters are significantly $(\mathrm{P}<0.05)$ different within columns.

\begin{tabular}{|c|c|c|c|c|c|c|c|c|}
\hline & Sand (\%) & Silt (\%) & Clay (\%) & $\mathrm{pH}$ & $\mathrm{BD}\left(\mathrm{g} / \mathrm{cm}^{3}\right)$ & OC (\%) & N (\%) & $\mathrm{C}: \mathrm{N}$ \\
\hline FM-O & $53.4 \pm 3.1$ & $26.6 \pm 1.8$ & $19 \pm .32$ & $6.17 \pm 0.18^{\mathrm{a}}$ & $1.13 \pm .08^{\mathrm{a}}$ & $1.3 \pm .18^{\mathrm{a}}$ & $0.19 \pm 0.03^{\mathrm{a}}$ & 10.95 \\
\hline FM-P & $52.7 \pm 3.3$ & $27.3 \pm 3.2$ & $20 \pm 2.3$ & $6.38 \pm 0.4^{\mathrm{a}}$ & $1.15 \pm 0.05^{\mathrm{a}}$ & $1.5 \pm 0.05^{\mathrm{a}}$ & $0.17 \pm 0.01^{\mathrm{a}}$ & 10.62 \\
\hline LM & $54 \pm 3.2$ & $27 \pm 1.5$ & $19 \pm 0.5$ & $6.3 \pm 0.05^{\mathrm{a}}$ & $1.32 \pm 0.03^{\mathrm{b}}$ & $1.8 \pm 0.03^{\mathrm{b}}$ & $0.11 \pm 0.01^{\mathrm{b}}$ & 16.34 \\
\hline VC-O & $52.9 \pm 0.2$ & $28.7 \pm 0.15$ & $18.4 \pm 0.56$ & $6.7 \pm 0.3 b$ & $1.04 \pm 0.02^{\mathrm{c}}$ & $2.01 \pm 0.4^{\mathrm{c}}$ & $0.24 \pm 0.01^{\mathrm{c}}$ & 8.37 \\
\hline VC-P & $53.2 \pm 0.4$ & $25.9 \pm 0.02$ & $20.9 \pm 0.08$ & $6.5 \pm 0.06^{\mathrm{a}}$ & $1.06 \pm 0.04^{\mathrm{c}}$ & $2.1 \pm 0.13^{\mathrm{c}}$ & $0.23 \pm 0.01^{\mathrm{c}}$ & 9.13 \\
\hline $\mathrm{C}$ & $54.8 \pm 3.2$ & $27.2 \pm 1.6$ & $18.0 \pm 1$ & $6.3 \pm 0.3^{\mathrm{a}}$ & $1.3 \pm 0.3^{b}$ & $1.6 \pm 0.2^{\mathrm{a}}$ & $0.12 \pm 0.02^{\mathrm{b}}$ & 13.4 \\
\hline
\end{tabular}

Table 3. Chemical composition of LM, FM-O, FM-P, VC-O and VC-P used in Pea crop experiments $( \pm$ SE, $n=5)$. Numbers followed by the same superscripts letter are not significantly different $(\mathrm{P}<0.05)$ within columns.

\begin{tabular}{|c|c|c|c|}
\hline & Organic carbon (\%) & Total Nitrogen (\%) & $\mathrm{C}: \mathrm{N}$ \\
\hline LM & $37.24 \pm 1.7^{\mathrm{a}}$ & $0.76 \pm 0.04^{\mathrm{a}}$ & $43.31^{\mathrm{a}}$ \\
\hline FM-O & $24.66 \pm 1.4^{\mathrm{b}}$ & $1.0 \pm 0.02^{\mathrm{b}}$ & $22.42^{\mathrm{b}}$ \\
\hline FM-P & $24.33 \pm 1.3^{\mathrm{b}}$ & $0.92 \pm 0.03^{\mathrm{b}}$ & $26.52^{\mathrm{b}}$ \\
\hline VC-O & $15 \pm 0.21^{\mathrm{c}}$ & $1.9 \pm 0.07^{\mathrm{c}}$ & $8.30^{c}$ \\
\hline VC-P & $14 \pm 0.84^{\mathrm{c}}$ & $1.5 \pm 0.02^{c}$ & $9.28^{c}$ \\
\hline
\end{tabular}




\subsection{Uptake of Nitrogen by the Pea Crop under Different Input Treatments}

The type of the manure input treatment affected the Nitrogen uptake by pea crop. It varied significantly between different treatments. It was higher for fruits $(\mathrm{F}[4,10]=68.21 ; \mathrm{P}<0.05)$, husk $(\mathrm{F}[4,10]=9.81 ; \mathrm{P}<0.05)$, stem $(\mathrm{F}[4,10]=7.56 ; \mathrm{P}<0.05)$ and roots $(\mathrm{F}[4,10]=10.03 ; \mathrm{P}<0.05)$ in plants which received VC-O followed by VC-P (Figure 2) as treatments.

\subsection{Effect of Different Input Treatments on the Yield of Pea Crop}

Seed germination, flowering and fruiting occurred earlier in the plots receiving VC-O and VC-P treatments as compared to other treatments. The higher germination percentage of $91.6 \%$ was recorded in VC-O and VC-P treated plots 11 days after sowing where as germination percentage was $85 \%$ - 85.45\% in FM-O and FM-P 14 days after sowing, the germination percentage was only $20 \%$ in $\mathrm{C}$ and occurred 16 days after sowing of seeds . Seedling growth was higher in VC-O and VC-P treated plots, and it was $12 \mathrm{~cm}$ in length as recorded after two weeks of sowing as compared to 8 and $8.3 \mathrm{~cm}$ in other treatments. Flowering emergence occurred between 80 to 82 days subsequent to seed sowing in VC-O and VC-P whereas it took about 84 to 85 days in FM-O and FM-P, and the number of flowers and pods was higher in VC-O and VC-P treated plots when compared to C, FM-O, FM-P and LM treated plots. Yield of pea crop varied significantly $(\mathrm{F}[4,10]=396.14$; $\mathrm{P}<0.05)$ between different treatments followed by VC-P as compared to FM-O, FM-P, LM and C (Figure 3). Fruit yield, leaf, stem and root biomass was significantly higher for VC-O.

\subsection{Effect of Different Input Treatments on Soil Faunal Biodiversity}

Total abundance of Entomobryomorphid $(\mathrm{F}[4,10]=632.7 ; \mathrm{P}<0.05)$, Sminthurids $(\mathrm{F} .[4,10]=776.4 ; \mathrm{P}<0.05)$,

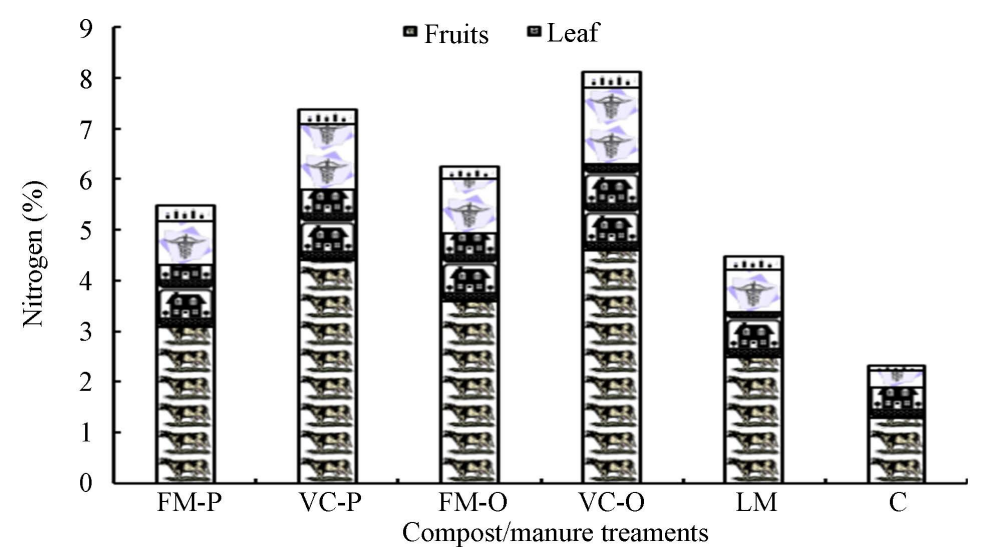

Figure 2. Effect of application of different treatments on nitrogen uptake by pea crop in agricultural system.

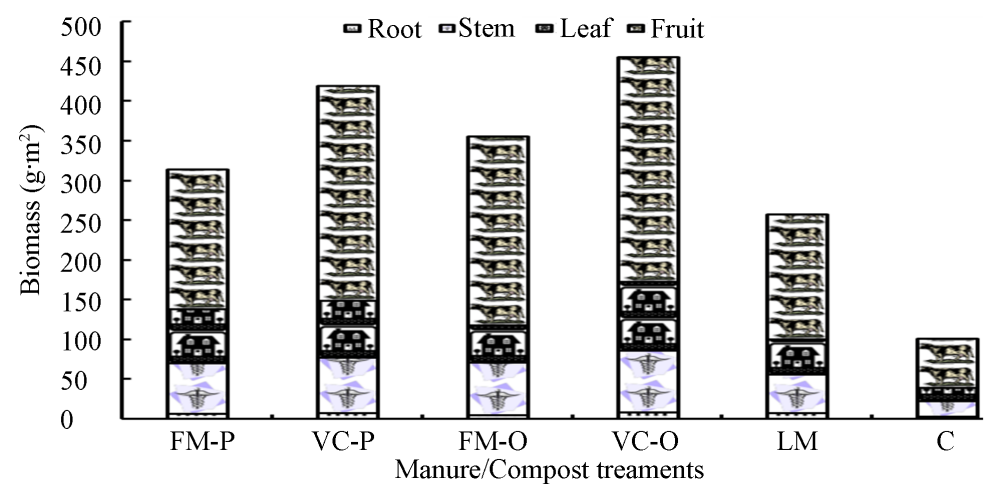

Figure 3. Effect of application of different treatments on production of Pea Crop in agricultural system. 
Podumorphs $(\mathrm{F}[4,10]=567 ; \mathrm{P}<0.05)$ and Acarina varied significantly between different treatments $(\mathrm{F}[4,10]=$ 377.4; $\mathrm{P}<0.05)$. Entomobryomorphid had significantly higher abundance $(\mathrm{q}[5,10]=69$; $\mathrm{P}<0.05)$ and biomass $(\mathrm{q}[5,10]=53 ; \mathrm{P}<0.05)$ in plots which received VC-P followed by VC-O (q $[4,10]=51.48 ; \mathrm{P}<0.05)$, Sminthurids had significantly higher abundance (q $[4,10]=43 ; \mathrm{P}<0.05)$ and biomass $(\mathrm{q}[4,10]=31 ; \mathrm{P}<0.05)$ in LM and lowest in FM-P (q [2,10] = 11.14; $\mathrm{P}<0.05)$. Podumorphs were significantly more abundant (q $[5,10]=54 ; \mathrm{P}$ $<0.05$ ) with higher biomass ( $\mathrm{q}[5,10]=37$; $\mathrm{P}<0.05)$ in FM-O followed by VC-O (q $[4,10]=43.26$; $\mathrm{P}<0.05)$, and were absent in plots with VC-P input. Acarina were significantly more abundant with higher biomass in VC-O (q [4,10] = 72.85; P < 0.05) and VC-P (q [5,10] = 37; P < 0.05 and lowest in FM-O (q [2,10] = 35.14; $\mathrm{P}<$ 0.05 ) when compared to other treatments. Abundance of mesoarthropods was significantly lower in $C$ plots. Abundance of Coleoptera $(\mathrm{F}[4,10]=280.93$; $\mathrm{P}<0.05)$, Larvae $(\mathrm{F}[4,10]=780,73 ; \mathrm{P}<0.05)$, Hymenoptera $(\mathrm{F}[4,10]=598.73 ; \mathrm{P}<0.05)$ and Arachnida $(\mathrm{F}[4,10]=12.58 ; \mathrm{P}<0.05)$ varied significantly between different treatments. Abundance ( $\mathrm{q}[4,10]=38.15 ; \mathrm{P}<0.05)$ and biomass of coleoptera was higher in FM-O and it did not vary significantly between other treatments. Abundance $(\mathrm{q}[3,10]=57.15 ; \mathrm{P}<0.05)$ and biomass $(\mathrm{q}[3,10]=$ 48.15; $\mathrm{P}<0.05$ ) of Larvae was higher in FM-O and were absent in LM. Hymenoptera were abundant in VC-O (q $[4,10]=57.15 ; \mathrm{P}<0.05)$ and had significantly higher biomass (q $[4,10]=66.23 ; \mathrm{P}<0.05)$ values followed by VC-P $(\mathrm{q}[4,10]=28.5 ; \mathrm{P}<0.05)$, these values were lower in FM-O and FM-P). Arachnida population was higher in VC-O (q $[4,10]=7.1 ; \mathrm{P}<0.05)$ and LM. Biomass of Arachnids did not vary significantly between FM-O and FM-P and VC-P, except for hymenoptera other macro arthropods were absent here (Table 4, Table 5).

Table 4. Total abundance of soil fauna (number $\left./ \mathrm{m}^{2}\right)$ in experimental plots under different treatments during cropping ( \pm SE, $\mathrm{n}=5$ ). Numbers followed by the same superscripts letter are not significantly different $(\mathrm{P}<0.05)$ within the rows.

\begin{tabular}{|c|c|c|c|c|c|c|}
\hline & LM & FM-O & FM-P & VC-O & VC-P & $\mathrm{C}$ \\
\hline Entomobryomorphid & $233 \pm 14^{\mathrm{a}}$ & $236 \pm 15^{\mathrm{a}}$ & $219 \pm 21^{b}$ & $327 \pm 12^{c}$ & $295 \pm 11.3^{\mathrm{d}}$ & $36 \pm 2.5^{\mathrm{e}}$ \\
\hline Sminthurids & $222 \pm 12.5^{\mathrm{c}}$ & $102 \pm 9^{\mathrm{a}}$ & $35 \pm 1^{b}$ & $68 \pm 3.2^{\mathrm{d}}$ & $70 \pm 6^{\mathrm{d}}$ & $16 \pm 0.6^{\mathrm{e}}$ \\
\hline Podumorpha & $241 \pm 2.3^{\mathrm{c}}$ & $395 \pm 21^{\mathrm{a}}$ & $22 \pm 1^{b}$ & $364 \pm 24^{d}$ & 0 & $5 \pm 0.3^{\mathrm{e}}$ \\
\hline Acarina & $1020 \pm 10^{\mathrm{b}}$ & $689 \pm 32^{\mathrm{a}}$ & $1073 \pm 64^{\mathrm{b}}$ & $1208 \pm 87^{\mathrm{C}}$ & $1186 \pm 112^{\mathrm{d}}$ & $12 \pm 0.9^{\mathrm{e}}$ \\
\hline Coleoptera & $7 \pm 0.1^{\mathrm{b}}$ & $44 \pm 3^{\mathrm{a}}$ & $7 \pm 0.24^{\mathrm{b}}$ & $11 \pm 0.10^{\mathrm{b}}$ & $7 \pm 0.4^{b}$ & 0 \\
\hline Larvae & $70 \pm 10^{c}$ & $140 \pm 3^{\mathrm{a}}$ & $95 \pm 2.2^{\mathrm{b}}$ & $13 \pm 0.1^{\mathrm{d}}$ & 0 & 0 \\
\hline Hymenoptera & $54 \pm 0.22^{\mathrm{a}}$ & $79 \pm 2^{a}$ & $151 \pm 10^{b}$ & $280 \pm 53^{c}$ & $202 \pm 17^{d}$ & $8 \pm 0.1^{\mathrm{e}}$ \\
\hline Arachnida & $11 \pm 1.1^{\mathrm{b}}$ & $7 \pm 0.2^{\mathrm{a}}$ & $7 \pm 0.3^{a}$ & $13 \pm 1.1^{\mathrm{b}}$ & $9 \pm 0.23^{\mathrm{a}}$ & 0 \\
\hline
\end{tabular}

Table 5. Total biomass of soil fauna $\left(\mathrm{g} / \mathrm{m}^{2}\right)$ in experimental plots under different treatments during cropping in Bhiri-Banswara village central Himalaya $( \pm S E, n=5$ ). India. Numbers followed by the same superscripts letter are not significantly different $(\mathrm{P}<0.05)$ within the rows.

\begin{tabular}{|c|c|c|c|c|c|c|}
\hline & LM & FM-O & FM-P & VC-O & VC-P & $\mathrm{C}$ \\
\hline Entomobryomorpha & $0.54 \pm 0.02^{b}$ & $0.46 \pm .02^{\mathrm{a}}$ & $0.48 \pm 0.15^{\mathrm{a}}$ & $1.15 \pm 0.12^{\mathrm{c}}$ & $0.98 \pm 0.03^{\mathrm{c}}$ & $0.043 \pm 0.01^{\mathrm{d}}$ \\
\hline Sminthurids & $0.22 \pm 0.07^{c}$ & $0.10 \pm 0.01^{\mathrm{a}}$ & $0.035 \pm 0.02^{b}$ & $0.068 \pm 0.03^{\mathrm{d}}$ & $0.07 \pm 0.02^{\mathrm{d}}$ & $0.016 \pm 0.001^{\mathrm{e}}$ \\
\hline Podumorpha & $0.41 \pm 0.1^{\mathrm{b}}$ & $0.59 \pm 0.01^{\mathrm{a}}$ & $0.58 \pm 0.01^{\mathrm{a}}$ & 0 & $0.05 \pm 0.01^{\mathrm{c}}$ & $0.01 \pm 0.001^{\mathrm{d}}$ \\
\hline Acarina & $1.10 \pm 0.05^{c}$ & $0.92 \pm 0.01^{\mathrm{a}}$ & $1.14 \pm 0.23^{c}$ & $1.36 \pm 0.1^{\mathrm{b}}$ & $1.18 \pm 0.2^{\mathrm{d}}$ & $0.003 \pm 0.001^{\mathrm{e}}$ \\
\hline Coleoptera & $7.93 \pm 1.2^{b}$ & $57.92 \pm 3.2^{\mathrm{a}}$ & $10.97 \pm 0.2^{\mathrm{b}}$ & $18.59 \pm 1.1^{\mathrm{b}}$ & $12.99 \pm 0.27^{\mathrm{b}}$ & 0 \\
\hline Larvae & $52.88 \pm 3.38^{\mathrm{a}}$ & $104.26 \pm 9.1^{\mathrm{b}}$ & $84.5 \pm 5.1^{\mathrm{a}}$ & $10.67 \pm 0.65^{c}$ & 0 & 0 \\
\hline Hymenoptera & $2.83 \pm 0.25^{\mathrm{a}}$ & $2.97 \pm 0.3^{\mathrm{a}}$ & $8.65 \pm 0.13^{b}$ & $8.25 \pm 0.09^{c}$ & $6.05 \pm 0.04^{\mathrm{c}}$ & $0.48 \pm 0.001^{\mathrm{d}}$ \\
\hline Arachnida & $1.32 \pm 0.05^{\mathrm{b}}$ & $0.39 \pm 0.12^{\mathrm{a}}$ & $0.67 \pm 0.01^{\mathrm{a}}$ & $1.48 \pm 0.05^{\mathrm{b}}$ & $0.87 \pm 0.05^{\mathrm{a}}$ & 0 \\
\hline
\end{tabular}




\subsection{Impact of Cropping Practice on Soil Faunal Diversity (Pitfall Traps) under Different Input Treatments}

Population density and biomass of Entomobryomorphid was significantly higher during cropping under all the treatments VC-O (F [2,6] = 110.23; P < 0.05), VC-P(F $[2,6]=110.55$; P < 0.05), FM-O (F $[2,6]=105.73$; P < $0.05)$, FM-P (F [2,6] = 106.55; $\mathrm{P}<0.05)$ except in LM where population increased subsequent to the crop harvest. As compared to other treatments, entomobryomorphid had significantly higher abundance during cropping under VC-O and VC-P treated plots (Figure 4(a)). Sminthurids were absent before the cropping was initiated however during cropping they had significantly higher population under all the treatments with a subsequent decline in post harvest period. The increase in population density was more prominent for plots receiving LM input treatment. Comparing the manure input treatment Sminthurids were more abundant with higher biomass during cropping in the FM-O (F [2,6] = 543.23; P < 0.05) than in VC-O. However the reverse was the case for FM-P (Figure 4(b)), they were absent both before and after cropping in C. Significantly higher abundance $(\mathrm{F}[2,6]=117.65 ; \mathrm{P}<0.05)$ and biomass of coleoptera occurred during cropping in VC-P, population density and biomass was significantly higher $(\mathrm{F}[2,6]=1143.43$; $\mathrm{P}<0.05)$ subsequent to the crop harvest only in FM-O. The population abundance did not show any significant variations during the cropping under other treatments and were absent in C. Abundance and biomass of coleoptera larvae was significantly lower during cropping periods in plots receiving VC-O (F [2,6] $=230.43$; $\mathrm{P}<0.05)$, VC-P (F $[2,6]=389.43 ; \mathrm{P}<0.05)$ as compost input. In the VC-P larvae abundance was higher before cropping, declined during the cropping period and they were absent subsequent to the crop harvest, they were absent in plots receiving LM treatment. They were most abundant and had higher biomass during cropping in FM-O (F [2,6] = 287.34; $\mathrm{P}<0.05)$, and FM-P treatment $(\mathrm{F}[2,6]=457.25 ; \mathrm{P}<0.05)$ but they were absent in C.

Hymenoptera were most abundant in plots receiving VC-O treatments, their population density and biomass declined under all the treatments during cropping except in the experimental plots receiving VC-O $(\mathrm{F}[2,6]=$ 481.9; $\mathrm{P}<0.05)$ and VC-P $(\mathrm{F}[2,6]=298.54$; $\mathrm{P}<0.05)$ treatments. However, the population density increased subsequent to crop harvest in FM-O (F [2,6] = 527.7; P < 0.05) and LM (F [2,6] = 307.52; P < 0.05) treated plots. Arachnida did not show significant differences between different treatments during cropping except in VC-O (F $[2,6]=85.3 ; \mathrm{P}<0.05)$. They were absent before cropping under all the treatments, increased in number during cropping and declined subsequent to the post-harvest period (Figures 5(a) and Figure 5(b)).

\subsection{Impact of Cropping Practice on Soil Faunal Diversity (Berlese Funnel Method) under Different Input Treatments}

Podumorphs had significantly higher density and biomass during cropping in C, FM-O (F [2,6] = 325; P < 0.05)

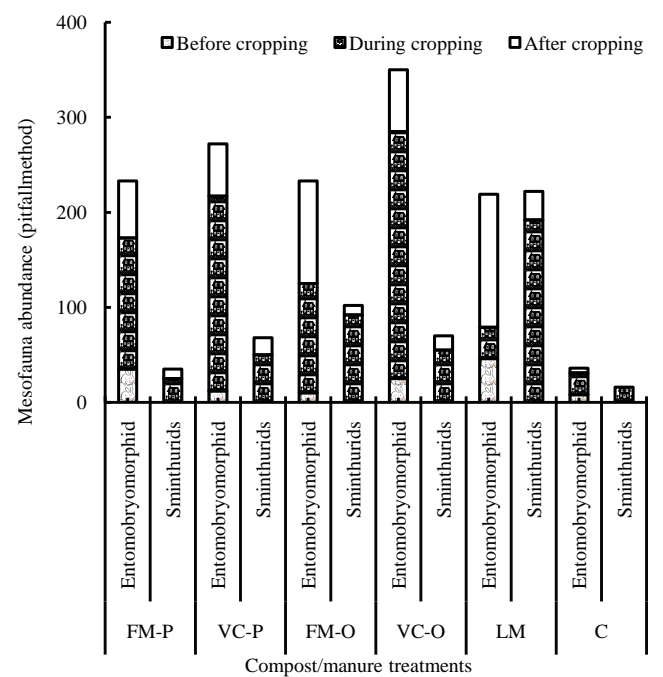

(a)

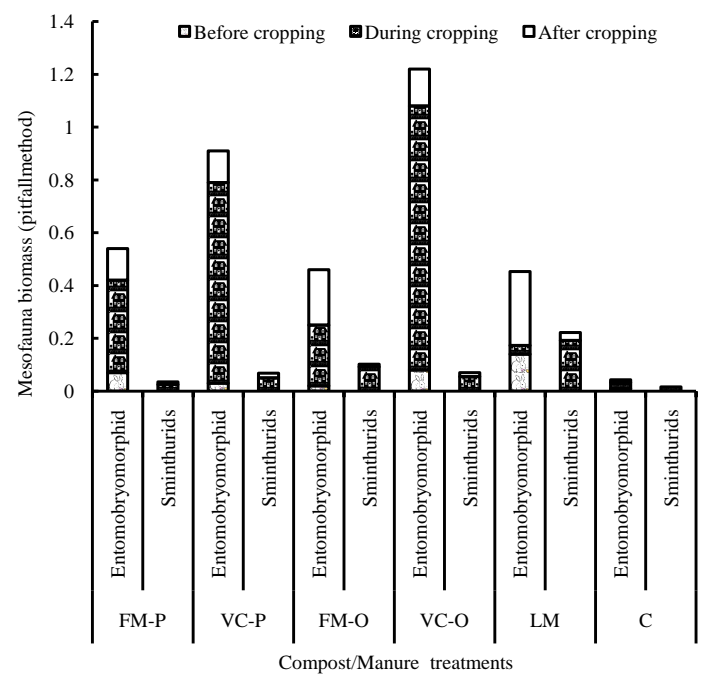

(b)

Figure 4. Effect of cropping pattern (pea crop) on abundance (a) and biomass of soil meso fauna diversity under different treatments, (Pitfall method) in agricultural system. 
and VC-O (F[2,6] = 543.88; $\mathrm{P}<0.05)$ and lower in FM-P. They were absent in plots receiving VC-P as nutrient source. They were absent subsequent to the harvest of crops under all the treatments. Acarina were more directly affected by the cropping activities and there abundance declined under all the treatments during the cropping period. Population density and biomass of Acarina was significantly higher before cropping in $\mathrm{C}$, VC-O $(\mathrm{F}[2,6]=$ 876.43; $\mathrm{P}<0.05)$ and VC-P (F[2,6] = 850; $\mathrm{P}<0.05)$ as compared to FM-O and FM-P (Figure 6(a) and Figure 6(b)).

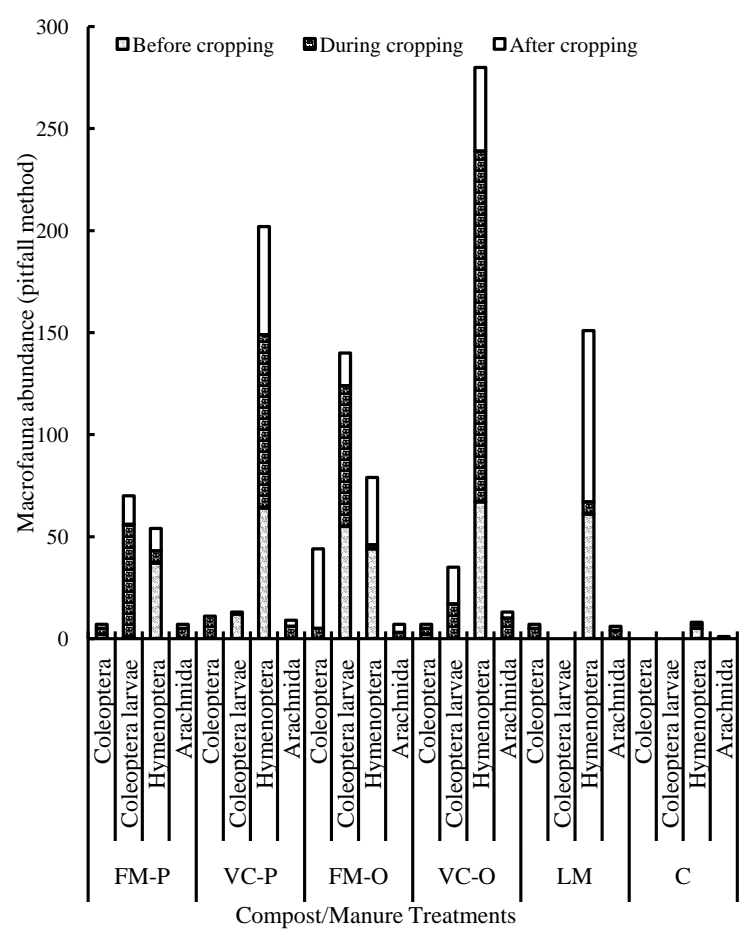

(a)

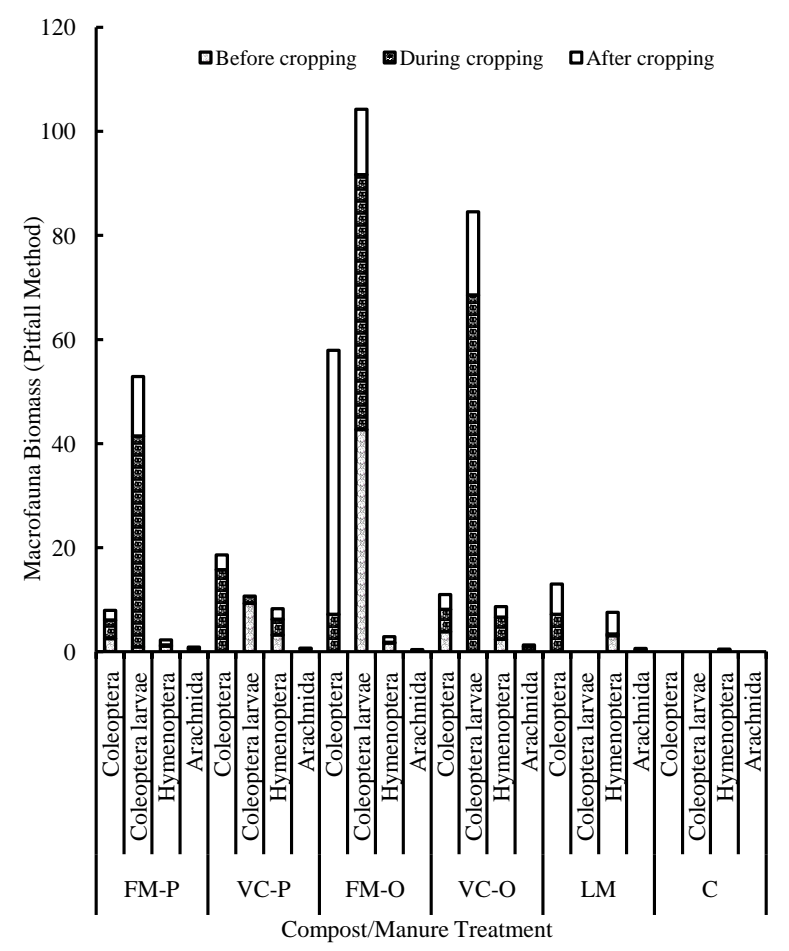

(b)

Figure 5. Effect of cropping pattern (pea crop) on abundance (a) and biomass (b) of soil macro fauna diversity under different treatments (Pitfall method) in agricultural system.

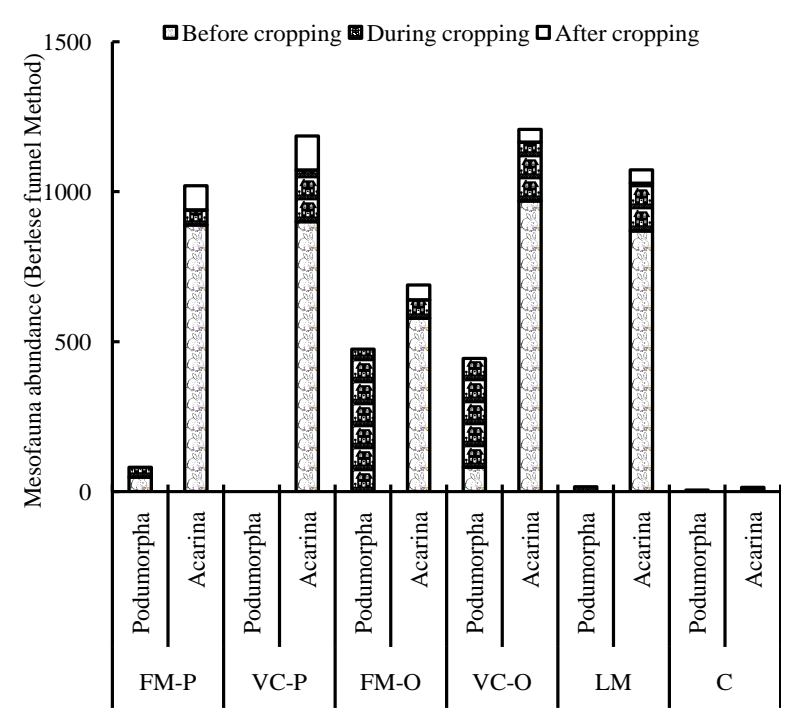

(a)

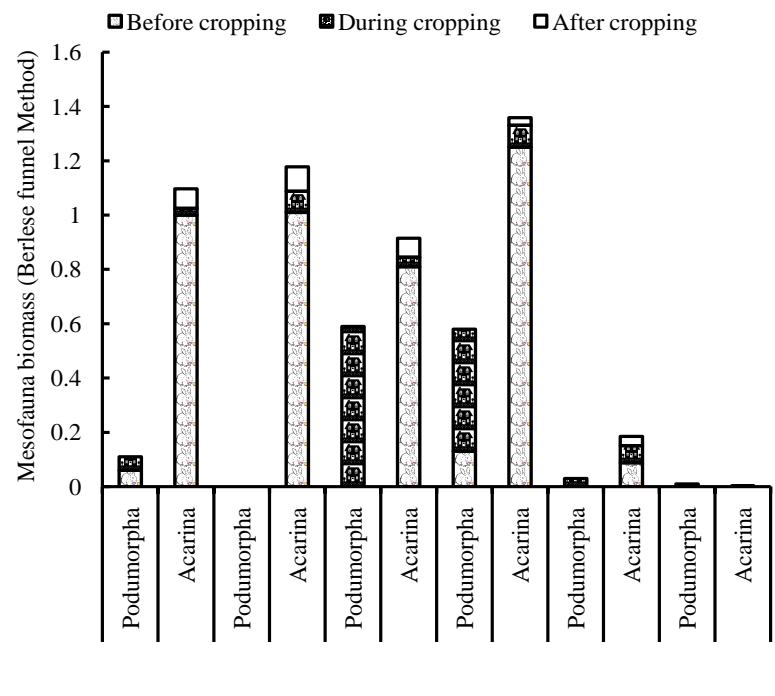

(b)

Figure 6. Effect of cropping pattern (pea crop) on abundance (a) and biomass (b) of soil meso fauna diversity under different treatments (Berlese funnel method) in agricultural system. 


\subsection{Simpsons Index of Diversity}

The diversity of soil fauna was higher in plots receiving VC-O treatment as nutrient source when compared to C, FM-P and VC-P treated plots. The soil faunal diversity did not vary significantly between VC-P and LM and was lowest in FM-P treated plots (Figure 7). Total soil faunal abundance and biomass was significantly lower in C $(\mathrm{F}[2,6]=70$; $\mathrm{P}<0.05)$, but addition of $\mathrm{VC}-\mathrm{O}$ when compared to other manure inputs to the treatment plots showed significantly higher total soil fauna abundance $(\mathrm{F}[2,6]=386.9 ; \mathrm{P}<0.05)$ and an higher yield of pea crop (Table 6).

\section{Discussion}

Pea crop grown in the experimental plots receiving VC-O, VC-P, FM-O, FM-P and LM material as nutrient sources showed the suitability of each of the product as a plant growth medium when compared to the $\mathrm{C}$.

\subsection{Soil Physicochemical Characteristics}

Improved soil physicochemical characteristics in the plots treated with vermicompost compared to conventional compost and C is because VC-O, VC-P amended plots have significantly higher soil bulk density [12] which improves the soil structure and aggregate stability of the particles compared to other treatments. It has been shown through our results and through the studies of other workers [13] that application of vermicompost favorably affects soil $\mathrm{pH}$ thereby improving microbial population and soil enzyme activities.

\subsection{Effect on Crop Growth}

Improved seed germination, enhanced rate of seedling growth, flowering and fruiting in VC-O and VC-P treated

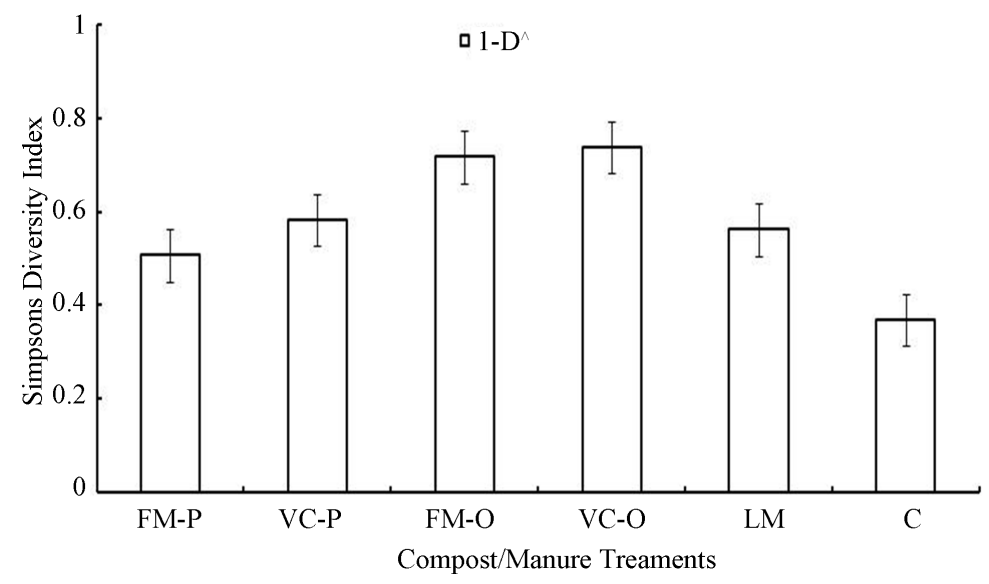

Figure 7. Change in the soil faunal diversity in response to different treatments and expressed as the Simpsons diversity index in Pea Crop agricultural system.

Table 6. Abundance and biodiversity of soil fauna as well crop yield in experimental plots under different treatments during cropping $( \pm S E, n=5)$. Numbers followed by the same letter are not significantly different $(P<0.05)$ within columns.

\begin{tabular}{|c|c|c|c|c|}
\hline & Simpson Diversity Index & Abundance of soil fauna $\left(\mathrm{No} / \mathrm{m}^{2}\right)$ & Biomass of soil fauna $\left(\mathrm{g} / \mathrm{m}^{2}\right)$ & Yield of Pea Crop $\left(\mathrm{g} / \mathrm{m}^{2}\right)$ \\
\hline LM & 0.562429 & $1689 \pm 57^{\mathrm{a}}$ & $147.95 \pm 76^{\mathrm{a}}$ & $257.6 \pm 4^{\mathrm{b}}$ \\
\hline FM-O & 0.716984 & $1705 \pm 143^{\mathrm{a}}$ & $40.78 \pm 2^{\mathrm{d}}$ & $355.5 \pm 12^{c}$ \\
\hline FM-P & 0.506881 & $1669 \pm 137^{\mathrm{a}}$ & $67.02 \pm 6^{c}$ & $313.8 \pm 7^{c}$ \\
\hline VC-O & 0.737699 & $2332 \pm 145^{\mathrm{b}}$ & $128.29 \pm 11^{\mathrm{b}}$ & $455.8 \pm 20^{\mathrm{e}}$ \\
\hline VC-P & 0.58287 & $1814 \pm 164^{\mathrm{c}}$ & $23.76 \pm 3^{c}$ & $419 \pm 11^{\mathrm{d}}$ \\
\hline $\mathrm{C}$ & 0.36894 & $78 \pm 14^{\mathrm{d}}$ & $0.552 \pm 0.02^{\mathrm{e}}$ & $169 \pm 9.4^{\mathrm{a}}$ \\
\hline
\end{tabular}


plots as compared to C, FM-O, FM-P and LM plots is because vermicompost has higher rate of plant growth hormones and humic acids. Higher humic acid stimulate root biomass and their numbers as has also been seen in our studies, thus giving the plant ability to scavenge nutrient from the surrounding environment for growth and development [14]. This causes increased efficiency of the rooting system, thus explaining enhanced plant growth.

\subsection{Nitrogen and Carbon, C: N Ratio}

Higher nitrogen level and lower $\mathrm{C}$ : $\mathrm{N}$ ratio in VC $(\mathrm{O})$ and $\mathrm{VC}(\mathrm{P})$ could be attributed to alteration of microbial nutrient spectrum in earthworm casts due to increased presence of nitrogen-fixing microbes which in turn enhance total nitrogen concentration in vermicompost [15]. Lower organic carbon \% in VC (O) and VC (P) can be explained as due to vermicomposting process lowering organic $\mathrm{C}$ from substrates through microbial respiration in the form of CO2 evolution [16]. Lower C: N ratio in VC (O) and VC (P) could be explained as due to mineralization and decomposition of organic matter, loss of carbon as carbon dioxide due to respiration, increased total $\mathrm{N}$ production through microbial activity and mucus and nitrogenous excreta during vermicomposting process. Higher $\mathrm{C}: \mathrm{N}$ ratio in LM could be attributed to the presence of high percentage of resistant constituents such as cellulose and lignin content [17].

\subsection{Nitrogen Uptake by the Pea}

Sailaja and Usha [18] reported that treatment with enriched vermicompost was superior to other treatments for the uptake of N, by cowpea (Vigna unguiculata). According to [19] the application of humic acids derived from vermicomposts, results in significant accumulation of $\mathrm{N}$ in the roots, shoots and fruits of the crops. This along with lower $\mathrm{C}: \mathrm{N}$ ratio in the vermicompost amended soils $\mathrm{VC}(\mathrm{O})$ and $\mathrm{VC}(\mathrm{P})$ explains the increased assimilation of mineral nitrogen uptake by the pea crops in our study.

\subsection{Effect on the Yield of Pea Crop}

The increased plant height and higher fruit, leaf and root biomass allocation in VC-O and VC-P treated plots as compared to C, FM-O, FM-P and LM treated plots can be explained as that the plant available nutrients are adsorbed on to the humates produced during the vermicomposting process [18] these are then gradually released into the soil solution thereby promoting a significant increase in plant growth, flowering and crop yields when compared to farm yard manure and conventional compost [20].

\subsection{Effect of Amendments on Soil Faunal Biodiversity}

Soil environment directly influences the soil faunal community with respect to numbers and composition and their spatial distribution. Increased numbers of Acarina, Collembola, in VC-O and VC-P amended plots when compared to C, FM-O, FM-P and LM treated plots may be explained as due to enhanced microbial population and activity in vermicompost when compared to conventional composts [21], this is also supported through the studies of Cole and Bardgett [22] who showed that the direct effect of vermicompost on collembola and acarina is driven by microbial rather than plant-derived resource availability response. Higher abundance and biomass of Acarina in the VC-O and VC-P treated plots as compared to C, FM-O, FM-P and LM is attributed to higher nitrogen as well as organic matter here. This is also supported by studies of Moore and Ruiter [23] who reported that the biomass of Acarina was greatest in sites receiving nitrogen, suggesting that more energy was transferred to higher trophic levels under these conditions also the higher organic matter improved the mite population thus suggesting the beneficial effects of these practices on the Acari community.

The preferences of Entomobryomorphs (spring tails) for feeding on decayed plant material and fungus mycelia and disintegrating macro- and mega fauna excrements resulted in there higher abundance in plots amended with VC-O and VC-P treatments, this has also been highlighted by the work of Haarlov [24] who showed that fungal feeding Collembola (springtails) and Acarina are higher in soil amended with vermicompost which favors fungal pathway. Vertical stratification of Collembola in soil is correlated with pore-size distribution, relative humidity and food availability [25]. The significantly higher abundance of Sminthurids (globular) collembola on LM amended plots as compared to C, FM-O, FM-P and VC-O and VC-P treatments was because they are inhabitants of superficial litter layers with preference for feeding on dead and decaying woody material and participating in disintegration of leaf litter [26]. The preference of Podumorphs to reside in the soil matrix and 
feed on organic matter rich substrate was probably the reason for their dominance in FM-O and VC-O amended plots [27] and the acidic nature of VC-P and FM-P could probably be one of the reason for their absence in VC-P amended plots. Dung in the farm yard manure is firstly exploited by the beetles and their larvae feed on decomposing organic debris and subsequently by the other litter-dwelling species [28], besides being important scavengers [29] and this thus explains the higher abundance and biomass of coleoptera and coleoptera larvae in the conventional FM-O treated plots when compared to VC-O and VC-P and C treatments. Presence of phenolics in vermicompost could also be one reason for lower abundance of larvae (arthropod pest) in VC-O and VC-P treated plots and therefore better resistance by crops to pests. According to [30], vermicompost forms part of the natural plant defense system against infection and harmful microbial invasions.

Higher abundance of Arachnida and Hymenoptera in VC-O and VC-P plots when compared to C, FM-O, FM-P and LM could be explained as due to the higher microbes number and improved nutrient status in the vermicompost-amended soils which have led to increased prey availability for them, as both Arachnida and Hymenoptera (ants) are predators that occupy the higher most position in the soil food web preying on other secondary consumers [31] [32]. This is also supported through the studies of [33] who highlighted the higher proportion of predators in the micro arthropod communities of vermicompost amended agricultural plots compared to conventionally amended plots, thereby suggesting that more energy is transferred to higher trophic levels under elevated soil fertility.

\subsection{Soil Faunal Biodiversity}

The change in the soil faunal diversity in $\mathrm{C}$ as well as in VC-O, VC-P, FM-O, FM-P, and LM and expressed as the Simpsons diversity index showed that the diversity is positively related to improvements in soil conditions resulting from nutrient manipulations through vermicompost and conventional compost treatments. This is also supported by the studies of workers [34] who showed that at a local scale the quality of crop residues and their distribution in the soil are major driving forces for soil biodiversity, and the responses of soil fauna to organic manure will depend on the manure characteristics, as well as the rates and frequency of application, quality of litter materials, habitat structure and local disturbance regimes. Macrofauna abundance and diversity relates to both soil fertility management and the agro-ecological conditions in different niches [35].

Increases in total soil faunal density and biomass with improvements in soil fertility and plant production in VC-O, VC-P when compared to FM-O, FM-P, and LM and C was because increased crop production most likely represents an increase in the availability of resources through addition of vermicompost when compared to other compost treatments. Chronosequence' study during pea cropping season indicates that the composition and abundance of soil fauna changed considerably with time under cultivation. Soil moisture in some ecosystems can be a stronger determinant of micro arthropod community composition than either vegetation or soil properties [36]. During cropping, increased quantity and quality of food supplied by vegetation resulted in greater fecundity, faster development and increased production and turnover of all the groups except Acarina, subsequently they increased or exhibited variable patterns such as peaks and troughs in abundance [37].

\section{Conclusion}

The present study therefore highlights that the application of vermicompost as compared to conventional compost improved the pea crop production in the region where it had declined due to poor land management practices. Addition of VC-O, VC-P and FM-O, FM-P, and LM created different niches in the treatment plots, and the niches had different diversity indices, which confirm that farmers' spatial-temporal management was translated into variations in biological status of the niches, also that different orders of soil arthropods coexist due to complimentarily of resource use through their varied life history tactics such as the larval stages, and by the complex structure of soils that enables extensive resource partitioning and niche differentiation. The complex relationships of soil fauna with their ecological niches in the soil, their limited mobility and their lack of capacity to leave the soil environment, make some taxa (e.g. Collembola, Acarina) particularly vulnerable to soil impact.

\section{Acknowledgements}

We are grateful to Dr. J.M. Julka for the help in taxonomic identification of earthworms, to the Director, G.B. Pant institute of Himalayan Environment and Development for facilities and to the TSBF-CIAT/UNEP/GEF and 
UNU-ISP for financial support.

\section{References}

[1] Bhadauria, T., Ramakrishnan, P.S. and Srivastava, K.N. (2000) Diversity and Distribution of Endemic Endemic and Exotic Earthworms in Natural and Regenerating Ecosystems in the Central Himalayas, India. Journal of Soil Biology and Biochemistry, 32, 2045-2054. http://dx.doi.org/10.1016/S0038-0717(00)00106-1

[2] Bhadauria, T. and Ramakrishnan, P.S. (1996) Role Of Earthworms In Nitrogen Cycle during the Cropping Phase of Shifting Agriculture (Jhum) in North-East India. Biology and Fertility of Soils, 22, 350-354. http://dx.doi.org/10.1007/BF00334582

[3] Nagavallemma, K.P., Wani, S.P., Stephane, L., Padmaja, V.V., Vineela, C., Babu Rao, M. and Sahrawat, K.L. (2004) Vermicomposting: Recycling Wastes into Valuable Organic Fertilizer. Global Theme on Agrecosystems Report No. 8. Patancheru, Andhra Pradesh, India: International Crops Research Institute for the Semi-Arid Tropics. Agriculture Review, 25, 29-39.

[4] Chaudhary, D.R., Bhandari, S.C. and Shukla, L.M. (2004) Role of Vermicompost in Sustainable Agriculture-A Review. Agricultural Review, 25, 29-39.

[5] Rajasekaran, B., Warren, D.M. and Babu, S.C. (1991) Indigenous Natural Resource Management System for Sustainable Agriculture Development-A Global Perspective. Journal of International Development, 3, 387-441. http://dx.doi.org/10.1002/jid.4010030312

[6] Kale, R.D. and Bano, K. (1988) Earthworm Cultivation and Culturing Techniques for Production of Vermicompost in Mysore. Journal of Agriculture Sciences, 22, 339-344.

[7] Bouyoucos, G.H. (1951) A Recalibration of The Hydrometer for Making Mechanical Analysis of Soils. Journal of Agronomy, 43, 434-438.

[8] Okalebo, J.R., Gathua, K.W. and Woomer, P.L. (1993) Laboratory Methods of Soil and Plant Analysis. A Working Manual. T.S.B.F., UNESCO-ROSTA, Nairobi.

[9] Walkley, A. and Black, I.A. (1934) An Examination of The Degtjareff Method for Determining Soil Organic Matter and Prepared Modification of the Chronic Acid Titration Method. Journal of Soil Science, 34, 29-38.

[10] Anderson, J.M. and Ingram, J.S.I. (1993) Tropical Soil Biology and Fertility. A Handbook of Methods, 2nd Edition, C.A.B. International, Wallingford, 221p.

[11] Zar, J.H. (1974) Biostatistical Analysis. Prentice-Hall, Englewood Cliffs, 620p.

[12] Arancon, N.Q., Edwards, C.A., Babenko, A., Cannon, J., Galvis, P. and Metzger, J.D. (2008) Influences of Vermicomposts, Produced by Earthworms and Microorganisms from Cattle Manure, Food Waste and Paper Waste, on the Germination, Growth and Flowering of Petunias in the Greenhouse. Journal of Applied Soil Ecology, 39, 91-99. http://dx.doi.org/10.1016/j.apsoil.2007.11.010

[13] Carpenter-Boggs, L., Kennedy, A.C. and Reganold, J.P. (2000) Organic and Biodynamic Management: Effects on Soil Biology. Soil Science Society America Journal, 64, 1651-1659. http://dx.doi.org/10.2136/sssaj2000.6451651x

[14] Perner, H., Schwarz, D. and George, E. (2006) Effect of Mycorrhizal Inoculation and Compost Supply on Growth and Nutrient Uptake of Young Leek Plants Growth on Peat-Based Substrates. Horticulture Science, 41, 628-632.

[15] Bachman, G.R. and Metzgen, J.D. (2008) Growth of Bedding Plants in Commercial Potting Substrates Amended with Vermicompost. Journal of Bioresource Technology, 99, 3155-3161. http://dx.doi.org/10.1016/j.biortech.2007.05.069

[16] Kale, R.D., Mallesh, B.C., Bano, K. and Bagyaraj, D.J. (1992) Influence of Vermicompost Application on the Available Macronutrients and Selected Microbial Populations in a Paddy Field. Soil Biology and Biochemistry, 24, 1317-1320. http://dx.doi.org/10.1016/0038-0717(92)90111-A

[17] Suthar, S. (2006) Effect of Vermicompost and Inorganic Fertilizer on Wheat (Triticum Aesticum) Production. Journal of Nature Environment \& Pollution Technology, 5, 197-201.

[18] Sinha, B., Bhadauria, T., Ramakrishnan, P.S., Saxena, K.G. and Maikhuri, R.K. (2003) Impact of Landscape Modification on Earthworm Diversity and Abundance in the Hariyali Sacred Landscape, Garhwal Himalaya. Journal of Pedobiology, 47, 357-370. http://dx.doi.org/10.1078/0031-4056-00199

[19] Kumari, M.S.S. and Ushakumari, K. (2002) Effect of Vermicompost Enriched with Rock Phosphate on the Yield and Uptake of Nutrients in Cowpea (Vigna unguiculata L. Walp). Journal of Tropical Agriculture, 40, 27-30.

[20] Edwards, C.A., Domínguez, J. and Arancon, N.Q. (2004) The Influence of Vermicomposts on Plant Growth and Pest Incidence. In: Shakir, S.H. and Mikhail, W.Z.A., Eds., Soil Zoology for Sustainable Development in the 21st Century, Self-Publisher, Cairo, 397-420.

[21] Breure, A.M. (2004) Soil Biodiversity: Measurements, Indicators, Threats and Soil Functions. International Confe- 
rence on Soil and Compost Eco-Biology, León, 15-17 September 2004, 83-96.

[22] Parthasarthi, R. and Ranganathan, H. (2001) Aging Effect of Microbial Population Enzyme Activities and NPK Content in the Soil Worm Cast of Lampito marutii and Eudrilus euginae Population. Journal of Pollution Research, 20, 53-57.

[23] Cole, L. and Bardgett, R.D. (2002) Soil Animals, Microbial Interactions and Nutrient Cycling. In: Lal, R., Ed., Encyclopedia of Soil Science, Marcel Dekker, New York, 72-75.

[24] Moore, J.C. and de Ruiter, P.C. (2000) Invertebrates in Detritus Food Web along Gradients of Productivity. In: Coleman, D.C. and Hendrix, P.F., Eds., Invertebrates as Webmasters in Ecosystems, CABI Publishers, Oxford, 161-184. http://dx.doi.org/10.1079/9780851993942.0161

[25] Gunadi, B., Blount, C. and Edwards, C.A. (2002) The Growth and Fecundity of Eisenia fetida (Savingy) in Cattle Solids Pre-Composted for Different Periods. Pedobiologia, 46, 15-23.

[26] Haarlov, N. (1955) Vertical Distribution of Mites and Collembola in Relation to Soil Structure. In: Mc Kevan, D.K.E., Ed., Soil Zoology, Butter Worths, London, 167-179.

[27] Christiansen, K. and Bellinger, P. (1998) The Collembola of North America. North of the Rio Grande. Grinnell College, Grinnell, 1322.

[28] Curl, E.A. and Truelove, B. (1986) The Rhizosphere. Springer-Verlag, Berlin.

[29] Curry, J.P. (1994) Influence on Soil Fertility and Effects on Plant Growth. Grassland Invertebrate Ecology. Chapman and Hall, London.

[30] Wardle, D.A. (2002) Communities and Ecosystems: Linking the Aboveground and Belowground Components. Princeton University Press, Princeton.

[31] Makoi, J.H.J.R. and Ndakidemi, P.A. (2007) Biological, Ecological and Agronomic Significance of Plant Phenolic Compounds in Rhizosphere of the Symbiotic Legumes. African Journal of Biotechnology, 6, 1358-1368.

[32] Singhai, P.K., Sarma, B.K. and Srivastava, J.S. (2011) Biological Management of Common Scab of Potato through Pseudomonas Species and Vermicompost. Biological Control, 57, 150-157. http://dx.doi.org/10.1016/j.biocontrol.2011.02.008

[33] Venier, L.A. and Pearce, J.L. (2006) The Use of Ground Beetles (Coleoptera: Carabidae) and Spiders (Araneae) as Bioindicators of Sustainable Forest Management: A Review. Ecological Indicators, 6, 780-793. http://dx.doi.org/10.1016/j.ecolind.2005.03.005

[34] Lisa, C., Bradford, M.A., Peter, J.A.S. and Bardgett, R.D. (2006) The Abundance, Richness and Functional Role of Soil Meso- and Macrofauna in Temperate Grassland-A Case Study. Journal of Applied Soil Ecology, 33, 186-198. http://dx.doi.org/10.1016/j.apsoil.2005.11.003

[35] Gessner, M.O., Christopher, M.S., Christian, K.D., Brendan, G., McKie, D., Richard, et al. (2002) The Effects of Cropping Systems and Fallow Management on Mi- croarthropod Populations. Journal of Plant Productive Science, 5, 257-265. http://dx.doi.org/10.1626/pps.5.257

[36] Tabu, I.M., Obura, R.K. and Swift, M.J. (2004) Macro Faunal Abundance and Diversity in Selected Farmer Perceived Soil Fertility Niches in Western Kenya. http://www.egerton.ac.ke/..../prof-isaiah-m-tabu-App.Ciat.Cgiar.Org

[37] Sileshi, G. and Mafongoya, P.L. (2006) Variation in Macrofaunal Communities under Contrasting Land Use Systems in Eastern Zambia. Applied Soil Ecology, 33, 49-60. http://dx.doi.org/10.1016/j.apsoil.2005.09.003 